\title{
研究論文
}

\section{デフォルメテンプレートを用いた飛行機キャラクター制作のための デザイン原案作成支援手法}

Designing Airplane Characters Using Deformation Templates

\author{
田中 希 Nozomi TANAKA \\ 岡本 直樹 Naoki OKAMOTO \\ 茂木 龍太 Ryuta MOTEGI \\ 近藤 邦雄 Kunio KONDO \\ 三上 浩司 Koji MIKAMI
}

\section{概要}

キャラクターデザインにおいて，設定資料などの文字情報 だけではディレクターのイメージした世界観に基づくデフォ ルメ形状が伝えづらい，そのためデザイナーとデイレクター との間にイメージギャップが生じ，作業効率が悪くなる。そ こで本論文では乗り物の例として飛行機に着目し，デフォル メの分析のために既存の飛行機キャラクターと実物の飛行機 の形状を部位ごとにサイズの比率を比較した。その結果をも とに，デフォルメテンプレートとしてまとめ、 $3 \mathrm{ds} \max$ 上 で簡易的に開発した形状変形システムを構築した。これによ り，半自動的に分析結果の傾向に合わせたデフォルメ変形を 可能にした。 そして提案システムを用いたデフォルメ形状制 作実験を行った。アンケート評価の結果，提案システムは キャラクターデザインの原案の制作に有効であることがわ かった.

キーワード：CG／キャラクターメイキング／デザイン原案 変形

\section{Abstract}

Anime characters often take the shape of deformed vehicles. However, it is often difficult for a director to convey his/her vision of character deformation to the designers through textual documents - which is the standard format by which they communicate. A communication gap forms where the designer cannot fully understand what the director has in mind, which subsequently leads to inefficiency and time loss during the design process. Our aim is to improve design efficiency for deformed vehicle characters. In this study, the vehicle we focused on was airplanes. We measured and compared the size and proportion of the different parts of airplanes and existing airplane-based characters. We summarized the data gathered into a deformation template, which we implemented into 3Ds max along with a simple deformation simulation system. As a result, we were able to perform deformation based on the deformation template in a semi-automatic matter. A questionnaire based evaluation showed that our system is indeed effective in designing characters.

Keywords: CG / Character Making / Design Sample / Deformation

\section{1．はじめに}

玩具屋では乗り物をモチーフにした玩具が多く販売さ れており ${ }^{[1]}$ ，テレビ放映したコンテンツに関連するキャ ラクターの玩具も多く販売されている．このことから子 供向けのコンテンツに対して乗り物をモチーフにした キャラクターの需要は大きいといえる. また，コンテン ツの多様化により，質の高いコンテンツの制作と魅力溢 れるキャラクターを作り出すことが望まれており ${ }^{[2] ， そ ~}$ のコンテンツに登場するキャラクターは頭身や形状など に誇張を加えるようなデフォルメされたものが多い.

コンテンツ制作の初期段階で行われるキャラクターメ イキングでは，プロデューサーなどの企画者がキャラク ターの基本設定を文字情報としてまとめたリテラル資料 をデザイナーへ渡し，そのリテラル資料を元にデザイ ナーがキャラクターの外見設定を絵で作成する ${ }^{[3]}$. しか し，文字情報だけでは企画者のイメージした作品の世界 観に基づくキャラクターのデフォルメ具合を伝えるのは 難しい. そのためデザイナーとプロデューサーの間にコ ミュニケーションギャップが生じ，作業効率が悪くな る.そこで重要なことは，プロデューサー側から大まか なキャラクターのイメージを視覚資料として提示する キャラクターデザイン原案である ${ }^{[4]}$. 文字資料と視覚資 料の 2 つをデザイナーへ渡すことにより，イメージの伝 達を容易にする。

デザイン原案とは，デザイナーへ企画者のキャラク ター外見イメージを伝えるためのものであり，本来の制 作目標であるデザイン画のように厳密に細かく描かれる 必要はない。デザイン原案を企画者があらかじめ作成し ておくことでデザイナーとの打ち合わせの場でキャラク ターの外見デザインの議論を行いやすくする．また，デ ザイナーはデザイン原案を基にし，絵を整えたりアレン ジを加えたりしてデザイン画（キャラクターの外見資 
料）を作成する．しかし，デザイン原案を作成するにあ たって, 既存の乗り物をデフォルメ化させることは絵を 描くことを不得手とする人にとって難しい作業である.

この課題を解決するために, 本研究では, このデフォ ルメキャラクターの特に形状を再現させることに特化し たデザイン原案作成支援手法を提案することを目的とす る. 本研究では乗り物の中でも飛行機に着目する。ま ず，既存の飛行機キャラクターと実物の飛行機の形状を 部位ごとに比較分析した. そして，その結果から得た数 值をデフォルメのテンプレートとしてまとめた. そして このテンプレートを用いて $3 \mathrm{~d} \mathrm{~d} \max$ 上で形状変形シス テムを構築し，評価実験を行った。

\section{2. キャラクターデザイン原案作成の従来手法}

\section{1. 先行研究}

\subsection{1. デザイン原案作成に関する先行研究}

コンテンツ制作の初期段階におけるデザイン原案作成 に関して，茂木ら ${ }^{[4]}$ は既存のキャラクターの画像を切り 貼りし，新しいキャラクターデザイン原案の作成を行う 手法を提案した。図 1 はそのシステムの画面例である. しかしこの研究には次の 2 つの課題がある.

(1)コラージュシステムでは 2D 画像を切り貼りして加 工するため，形状を変形した例を比較評価するために多 くの元画像が必要である.

(2) 2D 画像を扱うために，一方向の画像しか生成でき ず，三面図を揃えるためにはユーザー自身がそれらに対 応する画像を作らなければならず効率が悪い。

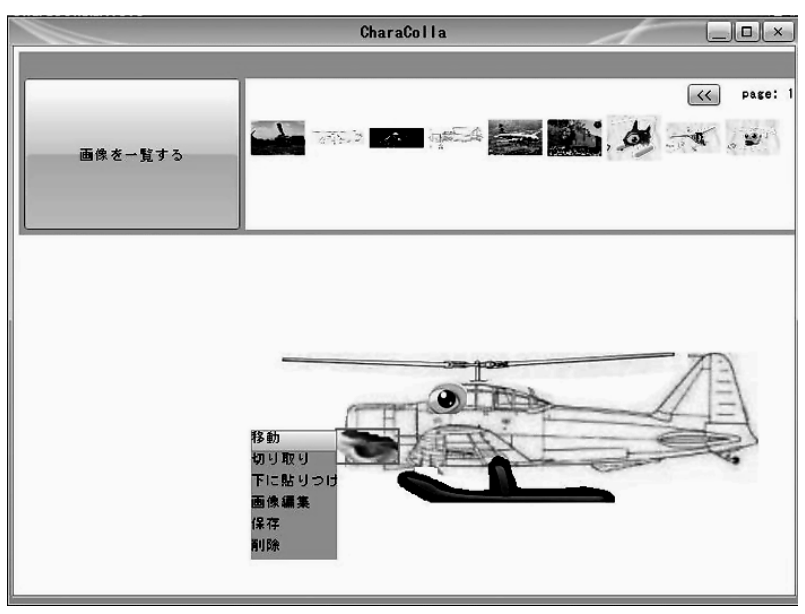

図 1 コラージュシステムの例

\subsection{2. 顔を対象としたデフォルメに関する先行研究}

森 ${ }^{[5]}$ はイラストレーターが人物のデフォルメされた似 顔絵を描く際に重視するポイントを調査した。また Nguyen Kim Hai Le ${ }^{[6]}$ は人間の顔形状を変形させる手 法を提案した. しかしそれらは人物の顔のデフォルメに
注目しており，全身のことは考慮されていない。

\subsection{3. 全身を対象とした変形に関する先行研究}

相馬 ${ }^{[7]}$ は 3 次元モデルの変形手法を提案したが，キャ ラクターデザイン原案作成段階において，デザイン意図 を容易に反映するようなデフォルメ情報の分析は行なっ ていない，そのため，デフォルメ化の指標となるものが なく，ユーザーが使用する際にデフォルメのイメージを 掴みづらい。

また，Md. Tanvirul Islam ${ }^{[8]}$ はデフォルメ形状とキャ ラクターの性格を関連付けた学習を行える手法を提案し た。しかし人間を対象としており，人間と異なる構造を したモチーフには対応していない.

\section{2. 既存の 3 次元CGソフトウェアにおけるモデル変形}

ここでは，既存の 3 次元 $C G$ ソフトを用いて 3 次元モ デルの変形にかかる時間について述べる. 図 2 , 図 3 に 使用したモデル，目標としたデフォルメキャラクターと 変形後のモデルを示す。図 3 はインターネット上でフ リー配布されているモデルである。この実験では図 2 の 3 次元形状モデルを図 3 (左図) のキャラクターの形状 と合致するように変形し，図 3 (右図) のデフォルメモ デルを作成した，変形はモデル全体への変形だけでな く，モデルの一部分などの細かい範囲に対して繰り返し 3 次元 $\mathrm{CG}$ ソフトの変形機能を適用して行った。この制 作実験の結果，図 2 のモ゙゙を図 3 (左図）の目標とす るデフォルメキャラクターの形状に変形させるまでに約 30分の作業時間がかかった.

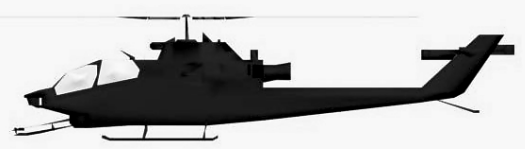

図 2 使用したモデル
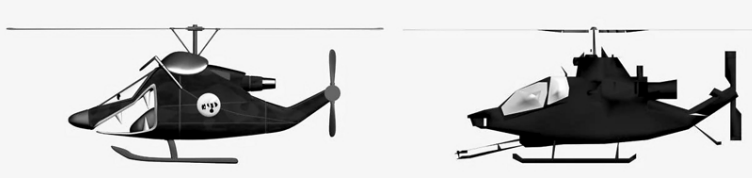

図 3 目標のデフォルメキャラクター(左), 変形結果 (右)

\section{3. 研究の手法}

先行研究や実際の制作事例の調査により，既存の手法 ではデフォルメキャラクターのデザイン原案を効率的に 作成するのが難しいことがわかった。 そこで本研究では $3 \mathrm{D}$ を用いた全身バランスを変えるデフォルメ手法を提 案することを目的とする．また，デフォルメの指標とな 
るデフォルメテンプレートを提示することにより，意図 したデフォルメ形状の制作と作業時間の短縮を目指す。

\section{3. デフォルメキャラクターの調査}

\section{1. 既存キャラクターの分析}

本研究では対象とする飛行機の機体を人間における頭 部や手などの部位に分け，それぞれに 3 次元形状の比率 を変化させて誇張を行うことを「デフォルメ」とする. 分析対象は『Sky Kids Booby ${ }^{[9]} 』 に$ 登場する飛行機キャ ラクター 9 体である. 分析対象のキャラクターには全体 的に丸みを帯びた形状のキャラクターが多く，形状の大 きさにも誇張が行われている．また，分析対象のキャラ クターにある飛行機部品や形状，キャラクターの飛行機 としての役割から実在する飛行機の機種を判断し, キャ ラクターのモチーフとしてその 2D 画像を収集した。

まず，既存の飛行機キャラクターとモチーフとなった 飛行機の構造を見比べながら比較し，デフォルメ分析の 基準となる部位を 12 力所に分けた。 その結果を表 1 に示 す.

表 1 分析基準の部位

\begin{tabular}{|c|c|c|c|}
\hline 頭部 & 腹部 & 腰部 & 尾 \\
\hline 目 & 鼻 & 翼 & 垂直尾翼 \\
\hline 水平尾翼 & エンジン内 & エンジン外 & プロペラ \\
\hline
\end{tabular}

各部位の名称はキャラクター化したときの制御パーツ を考慮して決定した。図 4 にキャラクターとモチーフの 画像にそれぞれ分析のために部位の対応付けをした画像 を示す。なお，この12力所に分けた部位の中には特有の 機種にしか対応しない部位も含んでいる。

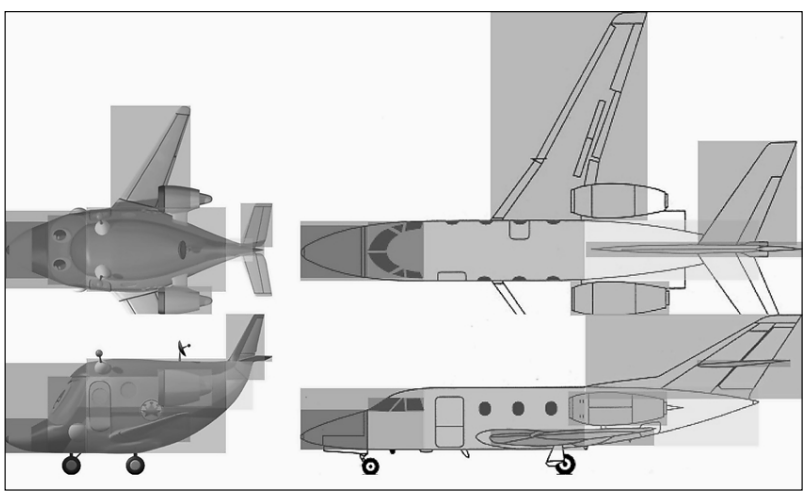

図 4 部位設定とデフォルメモデルと元モデルの比較

次にキャラクターとそのモチーフの上面・側面画像を 用意し, Illustrator 上で機体の高さを合わせるように 画像の大きさを同じ pixel 数になるように調整した。そ の後，それぞれの画像における各部位を色のついた四角 で囲み，その四角の縦横の幅を pixel 単位の数值で抽出
した，その抽出したデータから，キャラクターとそのモ チーフの各部位における幅 $(\mathrm{X}) \cdot$ 長さ $(\mathrm{Y}) \cdot$ 高さ $(\mathrm{Z})$ の值 をそれぞれ取得した。

\section{2. デフォルメテンプレートの作成}

前節で取得した值を用いて，モチーフの形状からキャ ラクターの形状へ変形させるときにどの程度の形状変化 が行われたかを計算し，各キャラクターのデフォルメの 形状比率を求めた。その結果を表 2 に示す.

表 2 飛行機キャラクターの形状比率の例

\begin{tabular}{|c|c|c|c|c|}
\hline 部位名称 & 頭部 & 腹部 & 腰 & 尾 \\
\hline 幅 (X) & $131 \%$ & $138 \%$ & なし & $39 \%$ \\
\hline 長さ (Y) & $66 \%$ & $87 \%$ & なし & $15 \%$ \\
\hline 高さ (Z) & $147 \%$ & $151 \%$ & なし & $82 \%$ \\
\hline 部位名称 & 目 & 鼻 & 翼 & 垂直尾翼 \\
\hline 幅 （X) & $123 \%$ & $108 \%$ & $49 \%$ & $79 \%$ \\
\hline 長さ (Y) & $113 \%$ & $63 \%$ & $49 \%$ & $18 \%$ \\
\hline 高さ （Z） & $359 \%$ & $86 \%$ & $185 \%$ & $77 \%$ \\
\hline 部位名称 & 水平尾翼 & エンジン & プロペラ & エンジン 2 \\
\hline (X) & $42 \%$ & $81 \%$ & なし & なし \\
\hline 長さ (Y) & $36 \%$ & $54 \%$ & なし & なし \\
\hline 高さ (Z) & $89 \%$ & $105 \%$ & なし & なし \\
\hline
\end{tabular}

また，算出した形状比率の数值からデフォルメテンプ レートを作成するために, 形状比率の増減傾向パターン を設定し，それを基に数值を整理した。

形状比率の増減傾向パターンは, 幅 $(\mathrm{X}) \cdot$ 長さ $(\mathrm{Y})$. 高さ $(\mathrm{Z})$ の 3 軸における形状比率を「100\%より大きい」 $\lceil 100 \%$ 未満」「100\%」の 3 項目で提示し，可能性のあ る 3 軸の組み合わせ 11 パターンとして定めた．表 3 に具 体的なパターンの増減傾向の内容を示す。

表 3 形状比率の増減傾向パターン

\begin{tabular}{|c|c|c|c|c|c|c|c|c|}
\hline & $\mathrm{A}$ & B & $\mathrm{C}$ & $\mathrm{D}$ & $\mathrm{E}$ & $\mathrm{F}$ & $\mathrm{G}$ & $\mathrm{H}$ \\
\hline 幅 & 0 & $x$ & $\bigcirc$ & 0 & $x$ & $x$ & 0 & $x$ \\
\hline 長さ & 0 & 0 & $x$ & 0 & $x$ & 0 & $\times$ & $\times$ \\
\hline \multirow[t]{2}{*}{ 高さ } & 0 & $\bigcirc$ & 0 & $x$ & 0 & $x$ & $\times$ & $\times$ \\
\hline & $\mathrm{C} \Delta$ & $\mathrm{E} \Delta$ & $\mathrm{G} \Delta$ & & & & & \\
\hline 幅 & $\bigcirc$ & $\times$ & $\triangle$ & & 0 & \multicolumn{3}{|c|}{ 100\%より大きい } \\
\hline 長さ & $\triangle$ & $x$ & $x$ & & $x$ & \multicolumn{3}{|c|}{ 100\%未満 } \\
\hline 高さ & 0 & $\triangle$ & $x$ & & $\triangle$ & \multicolumn{3}{|c|}{$100 \%$} \\
\hline
\end{tabular}

次に表 3 の増減傾向パターンをキャラクターの各部位 の形状比率に割り当てた。表 2 で示した形状比率の例に 対して表 3 の増減傾向パターンを割り当てた結果を表 4 に示す。 
表 4 増減傾向パターンを割り当てた例

\begin{tabular}{|c|c|c|c|c|}
\hline 部位名称 & 頭部 & 腹部 & 腰 & 尾 \\
\hline 幅（X） & $131 \%$ & $138 \%$ & なし & $39 \%$ \\
\hline 長さ (Y) & $66 \%$ & $87 \%$ & なし & $15 \%$ \\
\hline 高さ (Z) & $147 \%$ & $151 \%$ & なし & $82 \%$ \\
\hline パターン & $\mathrm{C}$ & $\mathrm{C}$ & なし & $\mathrm{H}$ \\
\hline 部位名称 & 目 & 鼻 & 翼 & 垂直尾翼 \\
\hline 幅（X） & $123 \%$ & $108 \%$ & $49 \%$ & $79 \%$ \\
\hline 長さ (Y) & $113 \%$ & $63 \%$ & $49 \%$ & $18 \%$ \\
\hline 高さ (Z) & $359 \%$ & $86 \%$ & $185 \%$ & $77 \%$ \\
\hline パターン & A & G & $\mathrm{E}$ & $\mathrm{H}$ \\
\hline 部位名称 & 水平尾翼 & エンジン & プロペラ & エンジン 2 \\
\hline$(\mathrm{X})$ & $42 \%$ & $81 \%$ & なし & なし \\
\hline 長さ（Y） & $36 \%$ & $54 \%$ & なし & なし \\
\hline 高さ （Z） & $89 \%$ & $105 \%$ & なし & なし \\
\hline パターン & $\mathrm{H}$ & $\mathrm{E}$ & なし & なし \\
\hline
\end{tabular}

割り当てられた増減傾向パターンの種類をキャラク ターごとにまとめた。そして同じ増隇傾向パターンの種 類が割り当てられたキャラクターを増減傾向のタイプと して分けた。また，さらにその増減傾向のタイプの中か ら，当てはまるキャラクターが多いタイプや，増減傾向 に特徵がみられるタイプなどを 5 つ選出した.

次に，選出した 5 つのタイプごとの各部位における増 減傾向パターンを新たに設定した。そして各軸の増減傾 向に当てはまる数値の平均值を算出し，その平均值を飛 行機形状のデフォルメテンプレートとした. 表 5 にデ フォルメテンプレートの值を\%単位で示す。このテンプ レートをデザイン原案作成支援システムで用いる.

また、表 5 におけるテンプレートの特徵は次に示す通 りである。

(1) “初期状態”：モデル形状の初期形状.

(2) “タイプA”：分析をした中で一番多い傾向が見られ た比率パターン。

(3) “タイプ B” : 飛行機の機体が細くなる傾向が特徴的 なパターン。

(4) “タイプC”：全体的にでっぷりと大きい形状が特徴 的な比率パターン.

(5)“タイプ D”：タイプ A と類似しているが，細かい部 分でタイプ A と異なる比率パターン.

(6) “タイプE”：すっきりした形状が特徽的な比率パ ターン.
表 5 デフォルメテンプレート

\begin{tabular}{|c|c|c|c|c|c|c|}
\hline 部位名称 & 初期状態 & タイプA & タイプ B & タイプC & タイプD & タイプE \\
\hline 頭部 & \begin{tabular}{l|l}
$\mathrm{X}$ & $100 \%$ \\
\end{tabular} & $196 \%$ & $75 \%$ & $196 \%$ & $196 \%$ & $196 \%$ \\
\hline & $100 \%$ & $65 \%$ & $65 \%$ & $222 \%$ & $65 \%$ & $222 \%$ \\
\hline & $100 \%$ & $158 \%$ & $158 \%$ & $158 \%$ & $158 \%$ & $158 \%$ \\
\hline 腹部 & $100 \%$ & $149 \%$ & $81 \%$ & $149 \%$ & $149 \%$ & $149 \%$ \\
\hline & $100 \%$ & $55 \%$ & $55 \%$ & $55 \%$ & $55 \%$ & $100 \%$ \\
\hline & $100 \%$ & $140 \%$ & $140 \%$ & $140 \%$ & $140 \%$ & $140 \%$ \\
\hline 腰部 & $100 \%$ & $169 \%$ & $43 \%$ & $169 \%$ & $169 \%$ & $169 \%$ \\
\hline & $100 \%$ & $37 \%$ & $37 \%$ & $177 \%$ & $37 \%$ & $37 \%$ \\
\hline & $100 \%$ & $148 \%$ & $77 \%$ & $148 \%$ & $148 \%$ & $148 \%$ \\
\hline 尾 & $100 \%$ & $58 \%$ & $58 \%$ & $58 \%$ & $155 \%$ & $155 \%$ \\
\hline & $100 \%$ & $41 \%$ & $41 \%$ & $41 \%$ & $41 \%$ & $192 \%$ \\
\hline & $100 \%$ & $79 \%$ & $79 \%$ & $79 \%$ & $138 \%$ & $138 \%$ \\
\hline 目 & $100 \%$ & $222 \%$ & $82 \%$ & $222 \%$ & $222 \%$ & $222 \%$ \\
\hline & $100 \%$ & $164 \%$ & $52 \%$ & $164 \%$ & $164 \%$ & $164 \%$ \\
\hline & $100 \%$ & $278 \%$ & $278 \%$ & $278 \%$ & $278 \%$ & $278 \%$ \\
\hline 鼻 & $100 \%$ & $180 \%$ & $96 \%$ & $180 \%$ & $180 \%$ & $180 \%$ \\
\hline & $100 \%$ & $254 \%$ & $60 \%$ & $254 \%$ & $60 \%$ & $254 \%$ \\
\hline & $100 \%$ & $143 \%$ & $143 \%$ & $143 \%$ & $143 \%$ & $143 \%$ \\
\hline 翼 & $100 \%$ & $54 \%$ & $54 \%$ & $54 \%$ & $54 \%$ & $137 \%$ \\
\hline & $100 \%$ & $53 \%$ & $53 \%$ & $53 \%$ & $53 \%$ & $126 \%$ \\
\hline & $100 \%$ & $66 \%$ & $66 \%$ & $66 \%$ & $145 \%$ & $145 \%$ \\
\hline 垂直尾翼 & $100 \%$ & $114 \%$ & $54 \%$ & $114 \%$ & $114 \%$ & $54 \%$ \\
\hline & $100 \%$ & $41 \%$ & $41 \%$ & $41 \%$ & $41 \%$ & $144 \%$ \\
\hline & $100 \%$ & $75 \%$ & $107 \%$ & $75 \%$ & $75 \%$ & $107 \%$ \\
\hline 水平尾翼 $\mathrm{X}$ & $100 \%$ & $60 \%$ & $60 \%$ & $60 \%$ & $60 \%$ & $172 \%$ \\
\hline & $100 \%$ & $44 \%$ & $44 \%$ & $44 \%$ & $44 \%$ & $145 \%$ \\
\hline & $100 \%$ & $61 \%$ & $100 \%$ & $61 \%$ & $61 \%$ & $154 \%$ \\
\hline エンジン $\mathrm{X}$ & $100 \%$ & $146 \%$ & $81 \%$ & $146 \%$ & $81 \%$ & $146 \%$ \\
\hline & $100 \%$ & $147 \%$ & $59 \%$ & $59 \%$ & $59 \%$ & $147 \%$ \\
\hline & $100 \%$ & $132 \%$ & $132 \%$ & $132 \%$ & $132 \%$ & $132 \%$ \\
\hline プロペラ & $100 \%$ & $104 \%$ & $73 \%$ & $104 \%$ & $104 \%$ & $104 \%$ \\
\hline & $100 \%$ & $174 \%$ & $50 \%$ & $174 \%$ & $174 \%$ & $174 \%$ \\
\hline & $100 \%$ & $104 \%$ & $73 \%$ & $104 \%$ & $104 \%$ & $104 \%$ \\
\hline エンジン $2 \quad \mathrm{X}$ & $\mathrm{X} \quad 100 \%$ & $140 \%$ & $63 \%$ & $140 \%$ & $63 \%$ & $140 \%$ \\
\hline & $100 \%$ & $127 \%$ & $50 \%$ & $50 \%$ & $50 \%$ & $127 \%$ \\
\hline & $100 \%$ & $140 \%$ & $140 \%$ & $140 \%$ & $140 \%$ & $140 \%$ \\
\hline
\end{tabular}

\section{4. デフォルメによるデザイン原案作成システ ムの概要}

\section{1. システムの概要とインターフェース}

本節では，前章で求めたデフォルメ比率を用いたデザ イン原案作成システムの概要とインターフェースについ て述べる。

本研究では前章の分析結果を元に，リアルな形状の飛 行機モデルを部位ごとに変形させてデフォルメキャラク ターのデザイン原案作成を支援するシステムを構築し

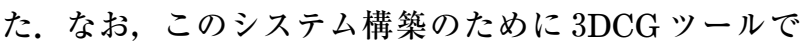
ある3ds max のスクリプト言語 MAX Scriptを用いる. 図 5 に本システムの概要を示す. 


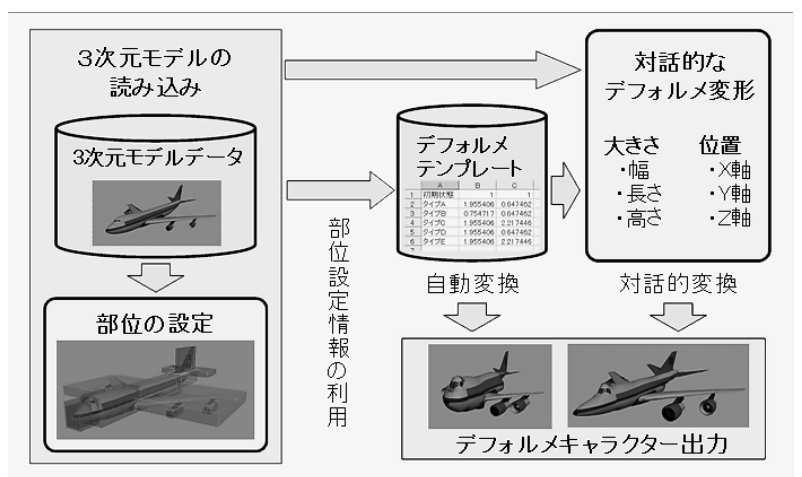

図 5 デザイン原案作成システムの概要

本システムは次の 2 つの機能から構成されている.

(1) 部位設定機能

ユーザーが用意した任意の飛行機モデルに対して前章 で述べた部位を設定する機能.

(2) 変形機能

分析結果から作成されたテンプレートとスライダーに よる微調整機能によってモデルを変形させる機能.

これらの機能を用いれば, リアルな形状の飛行機モデ ルを部位ごとにデフォルメすることができる．部位設定 機能と変形機能のインターフェースを図 6 と図 7 に示 す.

\section{2. 提案システムの部位設定と変形機能}

\subsection{1. 部位設定機能}

本システム起動後, $3 \mathrm{ds} \max$ 上で任意の飛行機モデ ルを選択し，図 $6(\mathrm{a})$ の上部にあるボタンを押すことによ り変形対象となるモデルの登録を行う. その後, 表 1 で 提示した各部位の位置をモデルの頂点を選択することに より指定する. 頂点が選択された状態で図 $6(\mathrm{~b})$ の)飛行機 の部位が描かれたボタンを押すことにより，選択された 頂点を全て内包する大きさのボックスモデルが生成され る.このボックスモデルは変形操作用のモデルであり, 必要部位に配置することによって部位設定を行う。図 8 にジェット機のモデルに頭部の部位を設定した例を示 す.

\section{2. 2. テンプレートと微調整による変形機能}

変形機能では，部位設定機能で設定した部位に対して 変形処理を行う。変形の際には, 飛行機モデルに対して スキンラップの機能を適応し, 変形操作用のボックスモ デルを拡大・縮小させることにより飛行機モデルへ変形 を加える．また，頭部に含まれている「目」と「鼻」に 関しては FFD という機能を適応し，頭部のスキンラッ プの影響を考虑した恋形を行っている. 図 $7(\mathrm{a})$ 上部のリ ストを変更することでモデル全体に表 3 のテンプレート

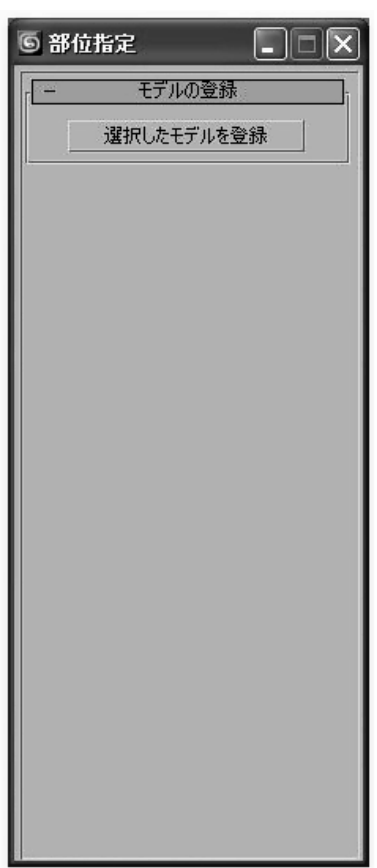

(a)

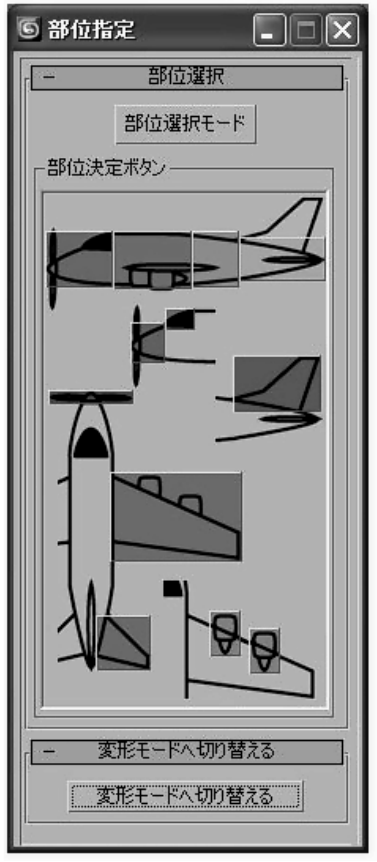

(b)
図 6 部位設定インターフェース

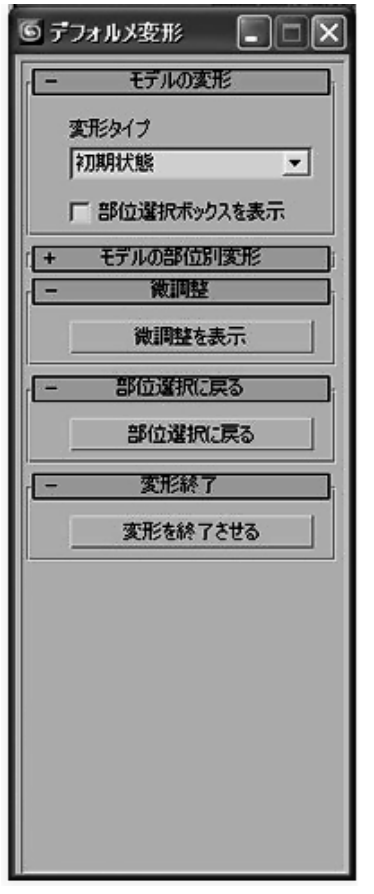

(a)

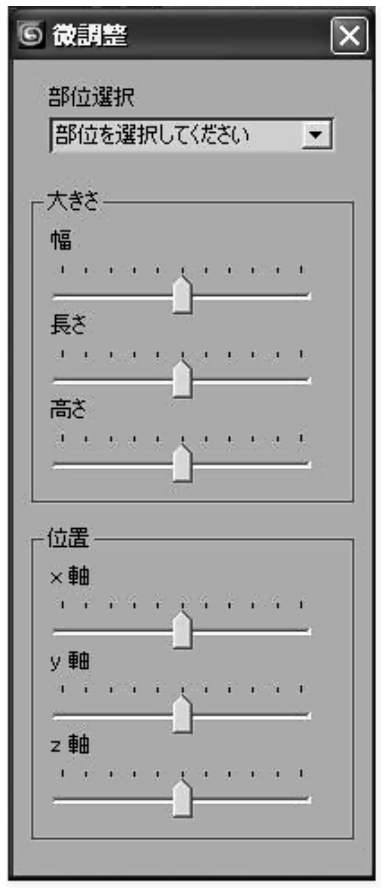

(b)
図 7 変形機能インターフェース

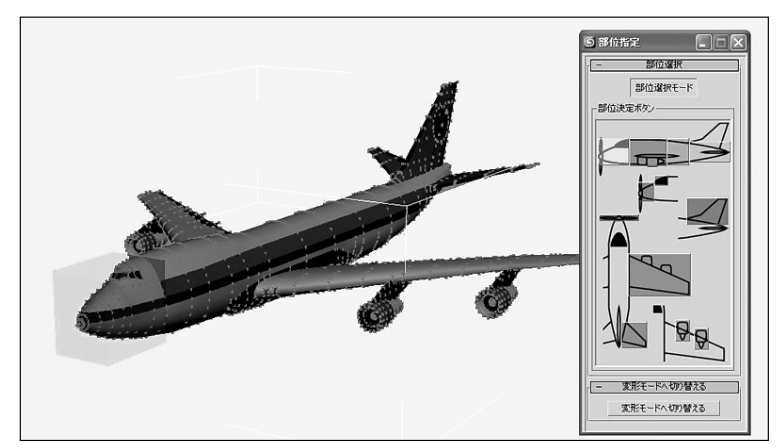

図 8 頭部設定の例 
に基づいた変形を行う。また，テンプレートは各部位ご とに異なったテンプレートを適用することも可能であ る. 具体的なテンプレートの適用例は次章で示す。最終 的な細かい変形の調整は図 $7(\mathrm{~b})$ のパラメーターを各部位 ごとに指定することにより行う。

\section{3. 変形テンプレートによる自動デフォルメと微調整} 図 9 から図14にそれぞれデフォルメのためのオリジナ ル形状，デフォルメテンプレートの適用結果 5 種類のモ デルを示す。

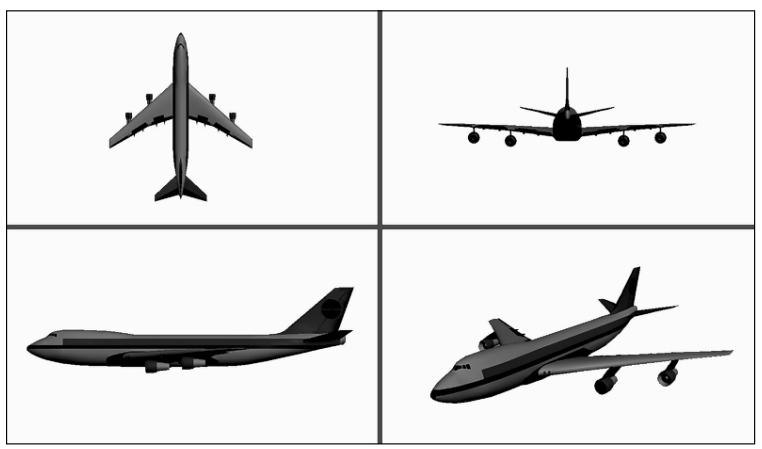

図 9 デフォルメのためのオリジナル形状

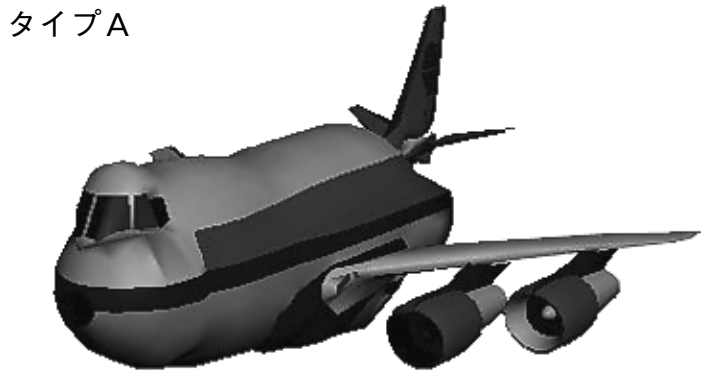

図10 デフォルメテンプレートの適用結果 1

$$
\text { タイプB }
$$

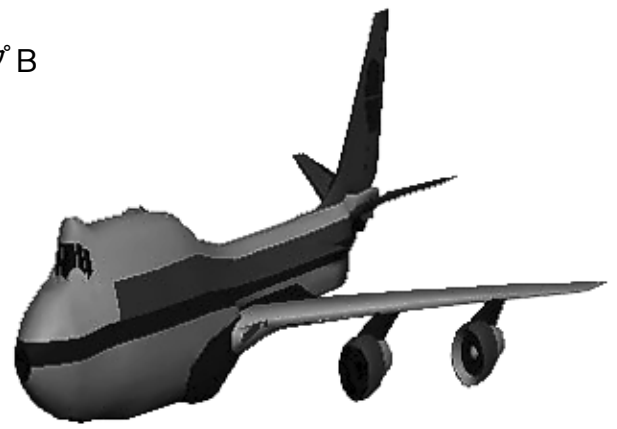

図11 デフォルメテンプレートの適用結果 2

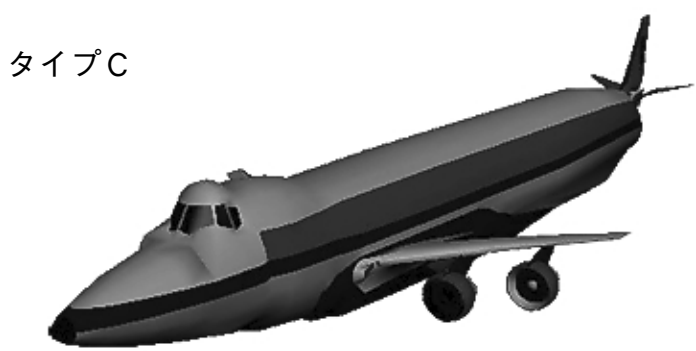

図12 デフォルメテンプレートの適用結果 3

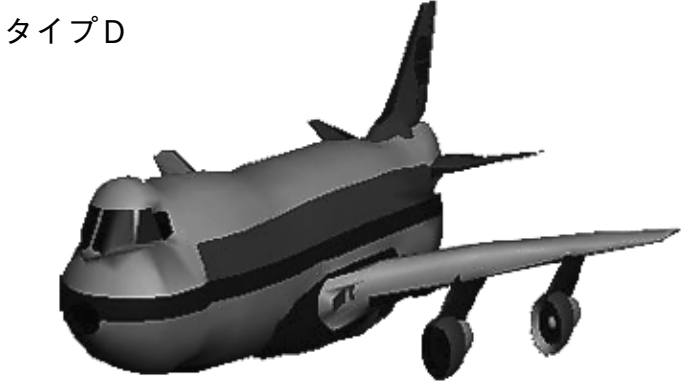

図13 デフォルメテンプレートの適用結果 4 タイプE

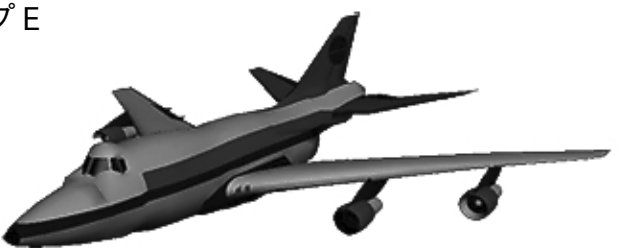

図14デフォルメテンプレートの適用結果 5

\section{4. 対話的なデフォルメ機能による制作実験}

オリジナルモデルを用いて対話的なデフォルメ変換に よるキャラクターの制作結果を図15と図16に示す。それ ぞれ，図15のモデルの場合は，デフォルメ時間が 2 分 12 秒， 1 分 43 秒，図16のモデルの場合は 2 分 13 秒， 2 分 39 秒であった．2.2節の実験と比較して90〜 93\%程度の短 縮が可能であることが分かる，ユーザーによる本システ ムの評価実験に関しては次章で述べる。

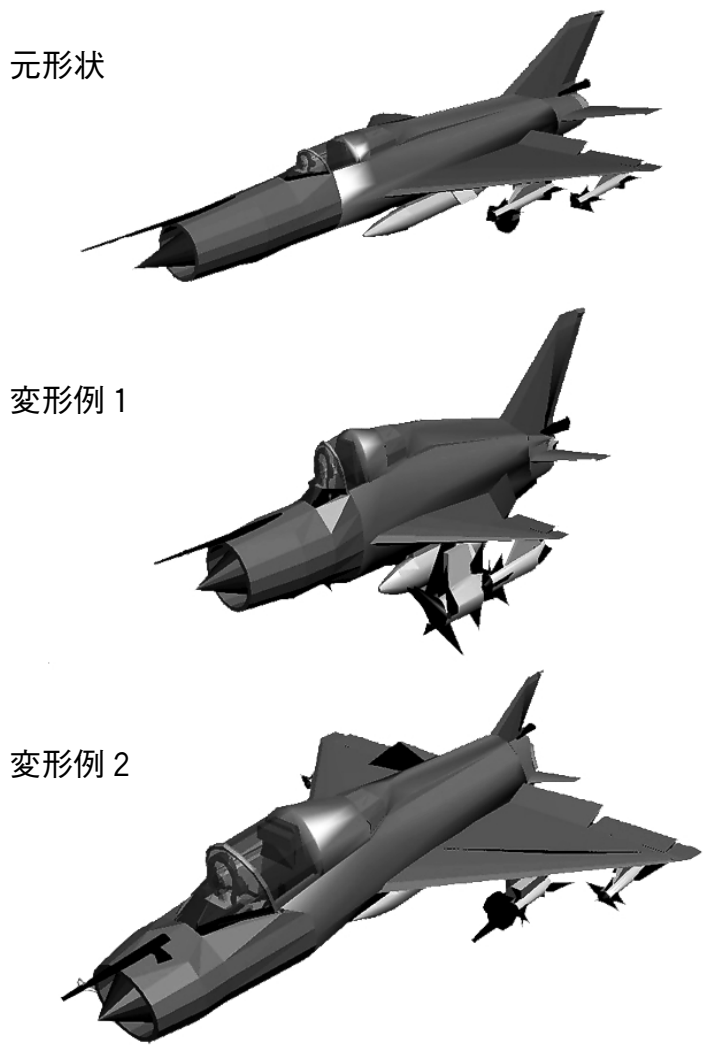

図15 対話的なデフォルメ制作結果 


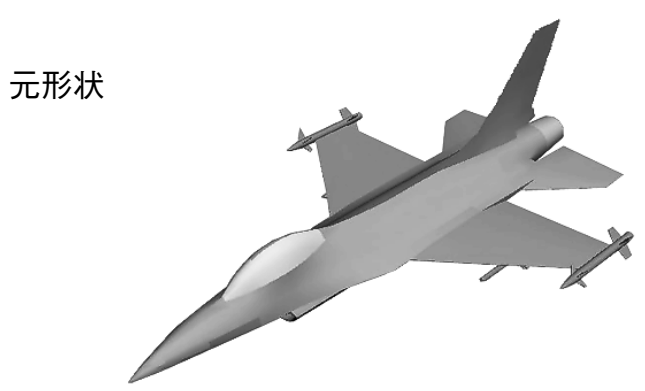

変形例 1

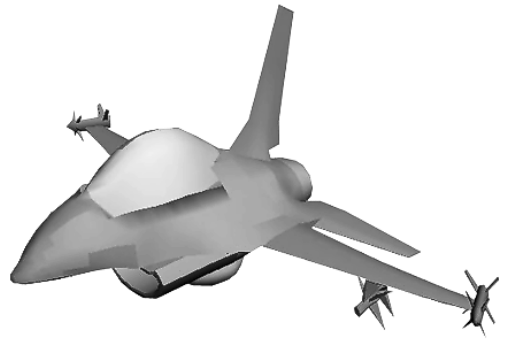

変形例 2

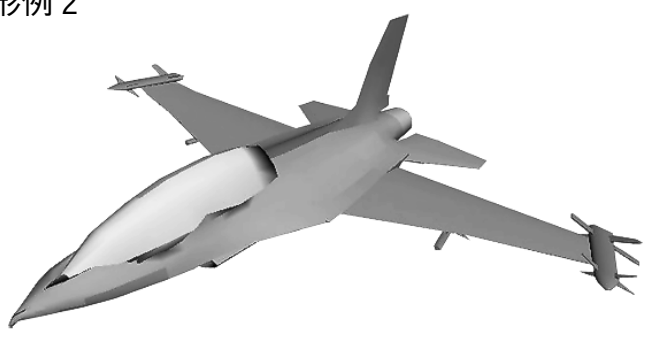

図16＼cjkstart対話的なデフォルメ制作結果

\section{5. デフォルメキャラクター生成評価実験と評価}

本研究で提案した手法の有用性, 及び変形機能とデ フォルメテンプレートの評価を得るために，次の変形機 能の評価実験を行った。評価実験では，実験用に用意し た部位設定の完了したモデルを使用し，目標のモデルに 形を近づけるように本システムを使用して変形を行うこ ととした．被験者は東京工科大学メディア学部・大学院 の学生 9 人である. 図17と図18に目標とする飛行機キャ ラクターモデルと被験者が作成した変形結果のモデルの 一例を示す．被験者の制作したモデルは大まかなデフォ ルメ形状を示すというデザイン原案としての品質は十分 である。図18のデフォルメ作業時間は 7 分 27 秒であっ た。また，本実験における 9 例の制作時間の平均は約 12 分程度であった。これにより 2.2 節で示した既存手法の デフォルメ制作作業時間と比較して，提案システムを用 いた場合，制作時間を約60\%短縮できたことが分かっ た。

本実験後, 被験者に対して評価アンケートを実施し た。その結果，本研究の提案手法の有用性に関わる問い では，「3D 上でデザイン原案を作成するのはキャラク
ターのイメージを掴みやすかったか」「部位ごとに変形 させる手法はデフォルメキャラクターのイメージを掴み やすかったか」という問いに対して，70\%，90\%が良い という評価であり，変形機能の評価に関わる問いでは 「目標のモデルを再現することができたか」という問い に対して $80 \%$ は良いという評価であった。デフォルメテ ンプレートの内容に関わる問いでは「デフォルメテンプ レートの項目は目標のモデルを再現するために有効か」 という問いに対して，70\%が良い評価であり，残りはど ちらでもないという回答であった。

アンケートの結果，本システムがユーザーの意図した デフォルメ変形を行うのに有効であるとわかった，以上 により，本システムではユーザーの意図した一定の品質 を保ち，作業時間を短縮することができた。しかしデ フォルメテンプレートに関するアンケートのコメントの 中には「テンプレートの数が少ない」や「変形後の形状 がイメージしづらい」という意見があった，今後，より デフォルメ作業を効率的に行うためには, 変形テンプ レートの充実を行う必要がある。

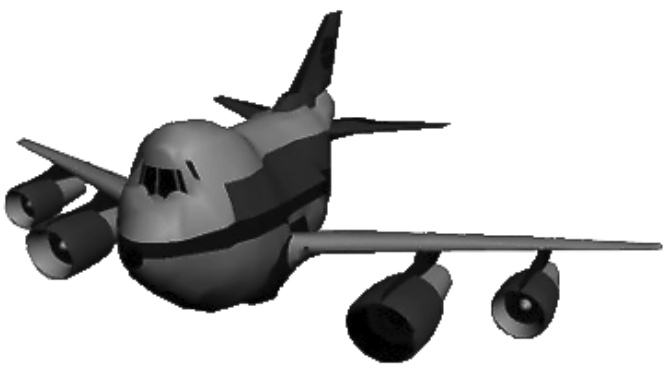

図17目標とする飛行機キャラクターモデル

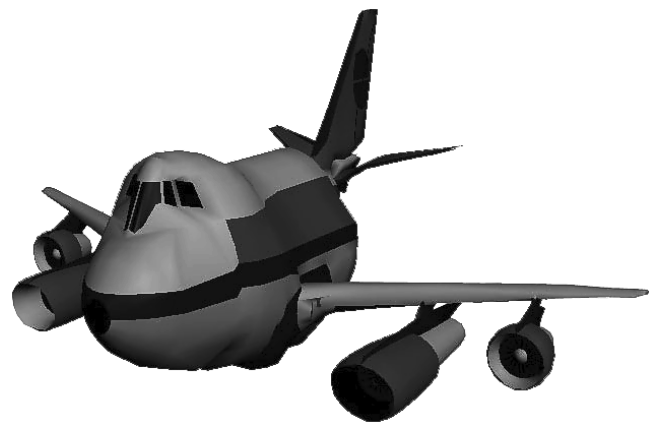

図18＼cjkstart被験者の作成したモデルの例

\section{6. まとめ}

本研究では, リアルな形状の飛行機モデルを部位ごと に変形するデフォルメテンプレートを提案し，デフォル メキャラクターデザイン原案制作システムを $3 \mathrm{ds}$ max 上で構築した。 そして本提案システムを用いて「デザイ ン原案作成者によるデフォルメキャラクター制作」とい う段階において，変形機能とデフォルメテンプレートの 
評価実験を行った.

この結果, 従来手法に比べて短時間でデフォルメキャ ラクターの形状を再現できることから，本システムはデ フォルメキャラクターのデザイン原案の制作に効果的で あり, 形状変形を効率的に行うための変形機能とデフォ ルメテンプレートが有用であることが分かった。本シス テムで作成したデザイン原案と文字資料であるリテラル 資料の 2 つを企画者がデザイナーへ渡すことにより，企 画者のイメージ伝達を容易にすることが考えられる.

また本研究では, 飛行機を例にデフォルメを行った が，同様の分析方法を用いれば，他のキャラクター形状 に対するデフォルメテンプレートを作成することができ るので、同様な効果を得ることが可能である。

今後の課題は，次のとおりである.

(1) デザイン伝達評価実験.

(2) より直感的なインターフェースの検討.

（3）さらなるデフォルメテンプレートの充実化.

\section{参考文献}

［1］ 小田玩具店, http ://www.omocyaya.com/,2009.

[2] 金子満, 近藤邦雄, 岡本直樹, 三上浩司, “創作テン プレートを用いたディジタルキャラクターメイキング 手法の提案”, NICOGRAPH 2009 春季大会, 芸術科 学会, (2009)

[3] 金子満, 映像コンテンッの作り方一コンテンツ工学の 基礎一，ボーンデジタル，(2007)

［4]茂木龍太, 岡本直樹, 高橋佳弘, 土田隆裕, 渡辺賢悟, 三上浩司，近藤邦雄，金子満，“ディジタルスクラッ プブックを用いたキャラクターデザイン原案制作シス テム”, 2009年度日本図学会春季大会学術講演論文 集，(2009)，50-55

［5］森大樹, 箕浦大祐, 前田泰宏, 安野貴之, 石橋聡, “3D キャラクタのデフォルメ表現方法に関する一検討”, 電子情報通信学会ソサイエテイ大会講演論文集, (2001), 210

[6] Nguyen Kim Hai Le, Yong Peng Why, Golam Ashraf, "Shape Stylized Face Caricatures", $M M M$ ' 11 Proceedings of the 17th international conference on Advances in multimedia modeling, Vol.1 (2011), 536-547

［7］相馬大作, 高井昌彰, 高井那美, “テンプレートを用 いた $3 \mathrm{D}$ キャラクターのデフォルメーションモデリン グ”, 情報処理学会研究報告 CG-123，(2006)，3741

[8] Md. Tanvirul Islam, Kaiser Md. Nahiduzzaman, Why Yong Peng, and Golam Ashraf, "Learning from Humanoid Cartoon Designs", ICDM'10 Proceedings of the 10th industrial conference on Advances in data mining: applications and theoretical aspects, (2010), 606-616.

[9] SKY KIDS BOOBY, http ://www.teu.ac.jp/clab/booby/,2009.
2011年 7 月 4 日受付

\section{たなか のぞみ}

東京工科大学大学院メディアサイエンス専攻在学中

CGアニメーション制作, キャラクターメイキングの研究に従事.

もてぎりゅうた

東京工科大学メディア学部 演習講師

武蔵野美術大学大学院卒業, 東京工科大学片柳研究所クリエイティブラ ボ研究員, キャラクターメイキングの研究に従事.

\section{おかもと なおき}

株式会社アクト・デザインズ

武蔵野美術大学卒業, 東京工科大学片柳研究所クリエイティブラボ研究 員, CG アニメーション企画, 制作, 映像コンテンツ制作の研究に従事.

みかみ こうじ

東京工科大学メディア学部 講師

1995年慶應義塾大学環境情報学部卒業, 博士（政策・メディア：2008年 慶応義塾大学). 主に3DCG を利用したアニメ, ゲームの制作技術と管 理手法に関する研究開発に従事. 著書に『アニメ学』(NTT 出版), 『デ ジタルアニメマニュアル』(東京工科大学) など. ACM SIGGRAPH, 芸術科学会, 情報処理学会, 日本デジタルゲーム学会ほか所属.

\section{こんどうくにお}

東京工科大学メディア学部 教授

名古屋工業大学卒業, 工学博士 (東京大学), 主に, コンピュータグラ フィックス, デジタル映像制作全般の研究に従事, 情報処理学会グラ フィクスと $\mathrm{CAD}$ 研究会主查, 画像電子学会副会長, ビジュアルコン ピューティング研究委員会委員長, 日本図学会副会長, 図学教育研究会 委員長など歴任. 現在, 芸術科学会会長. 